\title{
MANAGEMENT OF ENDOCRINE DISEASE
}

\section{Epidemiology, quality of life and complications of primary adrenal insufficiency: a review}

\author{
Sophie Bensing', Anna-Lena Hulting'2 ${ }^{2}$ Eystein S Husebye ${ }^{3,4}$, Olle Kämpe ${ }^{5}$ \\ and Kristian Løvås ${ }^{3,4}$ \\ 'Department of Molecular Medicine and Surgery, Karolinska Institutet, and Department of \\ Endocrinology, Diabetes and Metabolism, Karolinska University Hospital, Stockholm, Sweden, \\ ${ }^{2}$ Department of Molecular Medicine and Surgery, Karolinska Institutet, Stockholm, Sweden, \\ ${ }^{3}$ Department of Clinical Science, University of Bergen, Bergen, Norway, ${ }^{4}$ Department of Medicine, \\ Haukeland University Hospital, Bergen, Norway, and ${ }^{5}$ Department of Medicine (Solna), Centre for \\ Molecular Medicine, Karolinska Institutet, and Department of Endocrinology, Diabetes and Metabolism, \\ Karolinska University Hospital, Stockholm, Sweden
}

Correspondence
should be addressed
to S Bensing
Email
sophie.bensing@ki.se

\begin{abstract}
In this article, we review published studies covering epidemiology, natural course and mortality in primary adrenal insufficiency (PAI) or Addison's disease. Autoimmune PAl is a rare disease with a prevalence of 100-220 per million inhabitants. It occurs as part of an autoimmune polyendocrine syndrome in more than half of the cases. The patients experience impaired quality of life, reduced parity and increased risk of preterm delivery. Following a conventional glucocorticoid replacement regimen leads to a reduction in bone mineral density and an increase in the prevalence of fractures. Registry studies indicate increased mortality, especially evident in patients diagnosed with PAI at a young age and in patients with the rare disease autoimmune polyendocrine syndrome type-1. Most notably, unnecessary deaths still occur because of adrenal crises. All these data imply the need to improve the therapy and care of patients with PAI.

\section{Incidence and prevalence}

During the first half of the twentieth century, tuberculosis was the predominant cause of primary adrenal insufficiency (PAI) $(1,2)$. As the prevalence of tuberculosis declined, the aetiology pattern changed dramatically $(3,4,5,6,7)$. Nowadays, autoimmunity is the most frequent cause $(>90 \%)$ of PAI in industrialised countries $(8,9)$. Other causes include infectious, genetic, metastatic, haemorrhagic, and infiltrative disorders and surgery and drugs, but they are all rare in adult patients. The first prevalence rate of PAI, 39 cases per million, was reported from London in 1968 (3). Subsequent investigations have revealed increasing numbers up to 221 cases per million, as found recently on Iceland (10) (Fig. 1). However, lower prevalence rates have been reported outside Europe $(11,12,13)$. The incidence has been estimated at $4-6$ cases

www.eje-online.org DOI: 10.1530/EJE-15-1242
() 2016 European Society of Endocrinology Printed in Great Britain per million per year and is probably on a rising course $(5,7,8,10,14,15,16)$.

Autoimmune PAI occurs either as an isolated entity or as part of autoimmune polyendocrine syndromes type-1 and -2 (APS-1 and APS-2) (17, 18, 19) (Table 1). APS- 1 is a rare, recessive monogenic disease that is caused by mutations in the autoimmune regulator (AIRE) gene, characterised by the presence of two of the three main components: PAI, hypoparathyroidism and chronic mucocutaneous candidiasis, which has been reviewed elsewhere (20). Recently, several monoallelic mutations in AIRE's PHD1-domain were found to be associated with a milder form of APS-1 masquerading sometimes as APS-2, often with vitiligo and pernicious anaemia as disease components (21). Isolated PAI and APS-2 share the same 


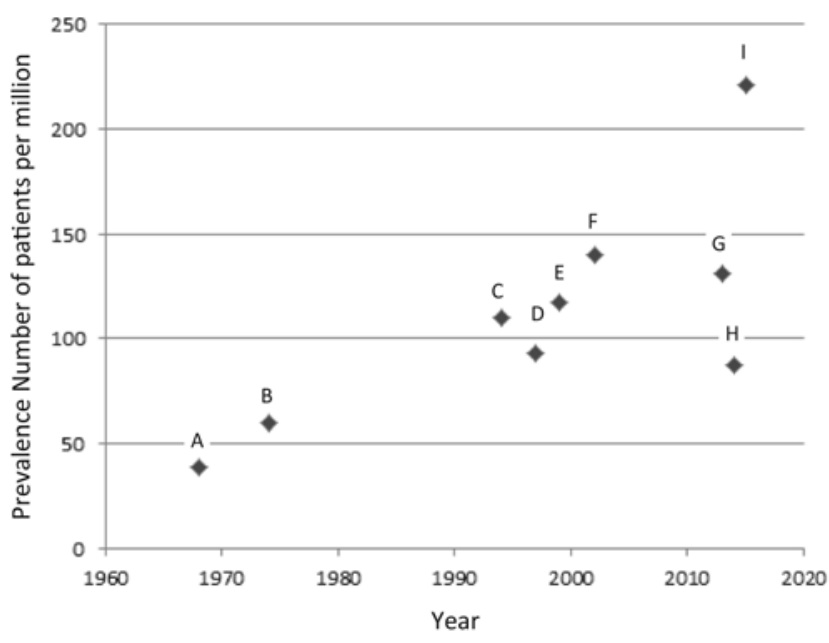

Figure 1

Historical overview of the epidemiology of primary adrenal insufficiency (PAI). Point prevalences of PAI in Europe. The prevalence rates were reported by A: Mason et al. (3), B: Nerup (4), C: Kong \& Jeffcoate (5), D: Willis \& Vince (6), E: Laureti et al. (14), F: Løvås et al. (7), G: Björnsdottir et al. (15), H: Meyer et al. (16) and I: Olafsson \& Sigurjonsdottir (10).

pattern of complex inheritance. In more than half of the cases PAI is a part of APS-2 $(8,19)$.

Autoimmune PAI can start at virtually any age, but commonly occurs in young and middle-aged individuals and extremely rare in children. Women are more often affected than men, but below the age of 30 , there is no gender difference. Conversely, among those with isolated PAI, there is a slight male predominance $(8,9,19)$.

\section{Health-related quality of life}

The current replacement regimens do not reproduce the normal diurnal variations of the glucocorticoid levels, but the consequences for the patients' health remain unknown $(22,23)$. Demonstration of treatment effects is challenging because there is no 'gold standard' for assessment of treatment efficacy. Circulating hormone levels do not necessarily reflect the cellular effects of these hormones, and at best, assay of cortisol profiles can only roughly guide glucocorticoid replacement therapy $(24,25$, $26,27,28)$. Several surveys undertaken by researchers or patient organisations have recorded common complaints before diagnosis and after treatment of PAI, but the majority of these studies do not give proper control data.
The most frequent symptoms at diagnosis are fatigue, loss of appetite, salt craving, vomiting and abdominal pain. Postural dizziness and pain in joints or muscles are also reported by a large number of patients. The most common signs are hyperpigmentation, hypotension and weight loss, which are observed in the majority. The frequencies of all the symptoms sharply diminish after replacement therapy is started, although many patients still report salt craving and postural dizziness while on replacement therapy (8).

Patients on replacement therapy reproducibly selfreport impairment in particular dimensions of general well-being questionnaires such as SF-36 $(8,29,30,31,32$, $33,34,35,36)$. General health and vitality perception are low for all patient subgroups, although the reductions are particularly pronounced for patients with concomitant type-1 diabetes (T1D). The quality of life (QoL) impairments have further been associated with female gender, increasing glucocorticoid dose, maladaptive personality traits, lower education and membership in patients' organisations $(34,35,37)$. One registry study indicated increased prevalence of affective disorders associated with PAI (38), and a cross-sectional study including 54 patients with PAI reported more irritability and somatic arousal (34).

Table 1 Manifestations of APS-1 and APS-2 (main components appear in bold).

\begin{tabular}{|c|c|c|}
\hline & APS-1 & APS-2 \\
\hline \multicolumn{3}{|l|}{ Manifestations } \\
\hline \multirow[t]{5}{*}{ Endocrine } & PAI & PAI \\
\hline & Hypoparathyroidism & $\begin{array}{l}\text { Autoimmune } \\
\text { thyroid disease }\end{array}$ \\
\hline & Ovarian failure & $\begin{array}{l}\text { Type } 1 \text { diabetes } \\
\text { mellitus }\end{array}$ \\
\hline & $\begin{array}{l}\text { Type } 1 \text { diabetes } \\
\text { mellitus }\end{array}$ & \\
\hline & $\begin{array}{l}\text { Autoimmune thyroid } \\
\text { disease }\end{array}$ & \\
\hline \multirow[t]{2}{*}{ Gastrointestinal } & $\begin{array}{c}\text { Autoimmune gastritis/ } \\
\text { pernicious anaemia }\end{array}$ & $\begin{array}{l}\text { Autoimmune } \\
\text { gastritis/ } \\
\text { pernicious } \\
\text { anaemia }\end{array}$ \\
\hline & $\begin{array}{l}\text { Autoimmune hepatitis } \\
\text { Intestinal } \\
\text { malabsorption }\end{array}$ & Coeliac disease \\
\hline \multirow{4}{*}{$\begin{array}{l}\text { Ectodermal } \\
\text { manifestations }\end{array}$} & Alopecia & Alopecia \\
\hline & Vitiligo & Vitiligo \\
\hline & Enamel dysplasia & \\
\hline & Keratoconjunctivitis & \\
\hline Hematological & Asplenia & \\
\hline Others & $\begin{array}{l}\text { Chronic } \\
\text { mucocutanous } \\
\text { candidiasis }\end{array}$ & \\
\hline
\end{tabular}


In other clinical studies, the mental health indices are mostly comparable to the background population. Interestingly, a recent study demonstrated that illness perceptions are associated with beliefs regarding medical therapy, i.e. that stronger beliefs and concerns about the impact of the glucocorticoid replacement are related to the patients attributing more symptoms and perceiving more negative consequences of PAI (39).

Questionnaires containing disease-specific items are likely to be more sensitive to effects that clinicians wish to monitor. Recently, the disease-specific questionnaire AddiQoL was developed (40) and validated (41) as an evaluative tool in PAI, which might facilitate the detection of minor changes in well-being in future clinical trials and during routine follow-up of patients $(42,43,44,45)$.

The normal sleep cycle and the cortisol rhythm are tightly synchronised, and disruption of the cortisol rhythm in stress or glucocorticoid treatment clearly affects sleep. One study showed increased prevalence of sleep disturbances in Addison's disease (46), and another indicated that glucocorticoid replacement is permissive for rapid eye movement (REM) sleep (47). One study found that, although PAI had a noteworthy direct effect on QoL, the indirect effect of sleep disruption was significantly greater (48). However, sleep quality in PAI and the impact of various replacement therapies have never been properly studied, and it remains unanswered whether disturbed sleep contributes to deficits in QoL. Furthermore, the glucocorticoid and mineralocorticoid receptors play important roles in cognition and memory, and some studies in PAI have indicated impairment of various aspects of cognition, although inconsistently $(49,50)$.

Ultimately, reduced functioning in these patients is evidenced by limitation of working capacity and a higher percentage receiving disability benefits than in the general population $(8,29,30)$.

\section{Sexuality}

Androgen deficiency is a hallmark of PAI in women. Although studies over the past few years have increased our knowledge on sexuality in patients with PAI, much is still not known. Sexual impairment could have various causes, including chronic fatigue, altered cortisol levels and androgen deficiency. The adrenals are a major source of androgens in women, and although the ovaries offer a significant contribution in healthy women, a contribution normally maintained after menopause (51), their role in females with PAI is minor. Females with PAI lack androgen precursors from the adrenals, whereas those with concomitant autoimmune premature ovarian insufficiency (POI), which occurs in 10-20\% of females with PAI, have a more complete androgen deficiency. The concentration of circulating androgens may, however, not reflect the effects at the cellular level, which may be better shown by the level of the testosterone metabolites (52). We have verified that the levels of $3 \alpha$-Diol-G are reduced, most significantly, in the subgroup of patients with POI (53).

One clinical trial demonstrated the beneficial effects of dehydroepiandrosterone (DHEA) replacement on sexual drive and satisfaction in females with adrenal insufficiency of primary and secondary aetiology (54). However, these effects were not replicated in studies that included only PAI patients $(31,55)$. Furthermore, despite the androgen depletion, female patients with PAI on a group level did not report impaired sexuality in any domain (53), which may however reflect subjective perception and not objective function. Miller and coworkers found improved sexual function with testosterone treatment (56) in severely androgen-deficient women with hypopituitarism, indicating that subgroups of PAI patients with complete androgen deficiency may possibly benefit from androgen replacement.

\section{Parity and pregnancy outcome}

A Norwegian postal survey found significantly fewer childbirths than expected from childbirth statistics after, but not before, the diagnosis of PAI, yielding a standardised incidence ratio (SIR) for birth of 0.69 (95\% confidence interval [CI], 0.52-0.86, $n=158$ ), after excluding patient with POI, 0.72 (95\% CI, 0.52-0.92) (53). A Swedish population-based epidemiological study including 1188 women with PAI also found that parity was significantly reduced after, but not before, the PAI diagnosis was made (57). Furthermore, the likelihood of having three or more children was less than onethird in women diagnosed with PAI compared with controls. Consequently, we now have data from two populations showing that PAI influences the number of childbirths. The reasons are unclear, but social, psychological, physiological and biological factors probably contribute.

There are only a little more than 100 reported pregnancy cases in women with PAI in the literature, but clinical experience is extensive. Untreated or 
mismanaged PAI results in high rates of adrenal crisis, maternal deaths and negative foetal consequences, i.e. intrauterine deaths, suboptimal birthweight and reduced foetal growth $(58,59,60)$. However, if provided adequate hormonal replacement, the majority of women can expect uneventful pregnancies of normal duration and without maternal or foetal compromise $(61,62,63$, 64). The first population-based epidemiological study on pregnancy outcomes in PAI was recently published, confirming that most pregnancies in women with PAI are uneventful (57). No maternal or infant deaths were reported, and there was no increase in risk of congenital malformations. However, more preterm deliveries (adjusted odds ratio (OR) 2.61; 95\% CI, 1.69-4.05) and caesarean sections (adjusted OR 2.35; 95\% CI, 1.68-3.27) were observed. Moreover, among 96 singleton infants born 3 years or less before their mothers were diagnosed with PAI had more frequent preterm births and lower birthweights. Notably, the risks were inversely correlated with time from delivery to the eventual PAI diagnosis. The underlying mechanisms are not known, but it is possible that suboptimal glucocorticoid levels before the diagnosis may alter the timing of delivery (65). Hormonal and immunoregulatory disturbances (more autoimmunity perhaps) preceding the diagnosis of PAI may account for the foetal growth retardation seen in infants born to mothers with undiagnosed PAI. The increased risk of a woman with PAI having a caesarean section may simply be treatment bias reflecting (unsubstantiated) concern for complications and possible adrenal crisis.

\section{Bone}

Glucocorticoids inhibit osteoblast activity, stimulate osteoclast activity and inhibit intestinal vitamin D-dependent calcium absorption, and osteoporosis is a feared complication of glucocorticoid therapy. Whether glucocorticoid-induced osteoporosis (GIOP) is also a problem with slight over-replacement, as commonly seen in patients with PAI, has not been well studied until recently. Some studies showed that reduction of glucocorticoid replacement doses improved markers of bone turnover $(25,66)$. A series of studies has shown an inconsistent correlation between bone mineral density (BMD) and disease duration, glucocorticoid type and dose in PAI $(27,67,68,69,70,71,72)$. A study of 294 patients from Norway, the UK and New Zealand showed a moderate though significant reduction in BMD in PAI patients (73), as had been indicated in the earlier, mostly underpowered studies. Notably, a recent study in 81 German PAI patients found no reduction in BMD (74). One likely explanation for the different findings is that the patients in the German cohort received lower doses of glucocorticoids (mean hydrocortisone equivalents: women $20.9 \mathrm{mg} /$ day, men $24.2 \mathrm{mg} /$ day) than the cohorts from Norway (women $31.5 \mathrm{mg} /$ day, men $33.2 \mathrm{mg} /$ day) and the UK and New Zealand (women $24.7 \mathrm{mg} /$ day, men $29.1 \mathrm{mg} /$ day).

The lack of adrenal androgens in patients with PAI could confer additional risk of osteoporosis. The largest DHEA trial so far in PAI suggested that 12-month DHEA replacement marginally but significantly increased BMD at the femoral neck but not at other skeletal sites (31). The German observational study showed that 17 female patients treated with DHEA had significantly lower markers of bone resorption and higher BMD Z-scores than those not receiving DHEA (74). One trial reported somewhat increased osteocalcin levels with DHEA treatment (75), whereas others found no effect of DHEA replacement on bone metabolism $(76,77)$.

Until recently, fracture data in PAI have been sparse. Thoracolumbar X-rays in 84 Norwegian patients older than 50 years did not show a higher prevalence of fractures than reported in the Norwegian reference population (73). However, a Swedish registry study that included 3219 patients over 30 years of age showed a significantly higher prevalence of hip fractures (6.9\%) compared with a reference population of 31557 age- and sex-matched controls (2.7\%; hazard ratio (HR) 2.7; 95\% CI, 1.6-4.5) (78). Interestingly, this study also indicated a significantly and unexplained increased risk of fractures in the patients before PAI diagnosis.

Little is known about individual susceptibility to GIOP in general or in patients with PAI. Using a candidate gene approach, Løvås et al. showed significant association between the common P-glycoprotein (ABCB1) SNP rs1045642 and BMD (73). Glucocorticoids are substrates for P-glycoprotein, and rs1045642 has previously been associated with reduced efficacy of this efflux transporter, which might increase intracellular glucocorticoid levels $(79,80)$. Most likely, individual susceptibility to GIOP is a multigenic and multifactorial challenge. The major clinical studies on bone and fractures are summarised in Table 2.

\section{Metabolism}

Glucocorticoids have profound effects on energy metabolism, but less is known about the metabolic status than bone status in PAI patients on replacement therapy. A study of 38 PAI patients on replacement therapy showed 
Table 2 Major clinical studies of metabolism, bone and fractures in primary adrenal insufficiency (PAI).

\begin{tabular}{|c|c|}
\hline Reference & Study type \\
\hline $\begin{array}{l}\text { Metabolism } \\
\text { Giordano } \\
\text { et al. (81) }\end{array}$ & Clinical study \\
\hline $\begin{array}{l}\text { Meyer } \\
\text { et al. (84) }\end{array}$ & Clinical study \\
\hline $\begin{array}{l}\text { Quinkler } \\
\text { et al. (43) }\end{array}$ & $\begin{array}{l}\text { Clinical study } \\
\text { Open, prospective } \\
\text { one-centre trial Baseline } \\
\text { and at follow-up } \\
\text { (median } 202 \text { days } \\
(85-498) \text { ). }\end{array}$ \\
\hline $\begin{array}{l}\text { Johannsson } \\
\text { et al. (85) }\end{array}$ & $\begin{array}{l}\text { Clinical study } \\
\text { Open, randomized, } \\
\text { two-period, 12-week, } \\
\text { crossover, multicentre } \\
\text { trial }\end{array}$ \\
\hline
\end{tabular}

Ross et al. Clinical study

(87)

$$
\begin{aligned}
& \text { Cross-sectional nationwide } \\
& \text { study }
\end{aligned}
$$

Björnsdottir Registry study Populationet al. (15) based cohort study

Ross et al. Clinical study (88)

Bone and fractures

Løvås et al. Clinical study $\quad$ PAI $=292$

\begin{tabular}{|c|c|c|}
\hline $\begin{array}{l}\text { Koetz et al. } \\
\text { (74) }\end{array}$ & Clinical study & $\mathrm{PAI}=81$ \\
\hline \multirow{2}{*}{$\begin{array}{l}\text { Gurnell } \\
\text { et al. (31) }\end{array}$} & Clinical trial & $\mathrm{PAI}=100$ \\
\hline & $\begin{array}{l}\text { Double-blind, randomized, } \\
\text { placebo-controlled, } \\
\text { 12-month, multicentre trial }\end{array}$ & $\begin{array}{l}50 \text { mg daily of oral DHEA } \\
\text { or placebo }\end{array}$ \\
\hline \multirow{2}{*}{$\begin{array}{l}\text { Bjørnsdottir } \\
\text { et al. (78) }\end{array}$} & Registry study & $\mathrm{PAI}=3219$ \\
\hline & $\begin{array}{l}\text { Population-based cohort } \\
\text { study }\end{array}$ & Controls = 31557 \\
\hline
\end{tabular}

(73)

\section{Sample}

$\mathrm{PAl}=38$ on conventional glucocorticoid treatment Controls $=38$

$\mathrm{PAI}=13$ on conventional glucocorticoid treatment

$\mathrm{PAI}=32, \mathrm{SAI}=18$

$21 \mathrm{PAI}$ and 9 SAI patients switched by their own decision from conventional glucocorticoid treatment to once-daily modified release hydrocortisone

$\mathrm{PAI}=64$

The same daily dose of hydrocortisone was administered as once-daily modified release or thrice-daily conventional hydrocortisone treatment

$\mathrm{PAI}=147$ on conventional glucocorticoid treatment

$\mathrm{PAI}=1305$

Controls $=11996$

$\mathrm{PAI}=110$ (55 Swedish and 55 South African)
Controls $=147$

\section{Result}

Mean waist higher $(P<0.05)$ in PAl. No difference for mean gluco-lipid levels but a higher percentage of PAI patients had impaired glucose tolerance ( 8 vs $0 \%$ ), hypercholesterolaemia ( 18 vs $8 \%$ ) and triglyceridemia (18 vs $8 \%$ )

Screening of hypoglycaemia using CGMS identified a nocturnal hypoglycaemic episode in one patient with blood glucose level clearly beneath the $95 \%$ tolerance interval of minimal glucose levels

Patients on once-daily modified release hydrocortisone showed significant decreases in BMI $(26.0 \pm 0.75$ to $25.6 \pm 0.71, P$ for change $=0.006)$ and $\mathrm{HbA} 1 \mathrm{c}(6.04 \pm 0.29$ to $5.86 \pm 0.28, P$ for change $=0.005)$. No change in these parameters was seen in patients remaining on conventional glucocorticoid treatment

Reduced mean body weight (difference $=-0.7 \mathrm{~kg}, P=0.005$ ), reduced systolic $B P$ (difference $=-5.5 \mathrm{mmHg}, P=0.0001$ ) and diastolic BP (difference: $-2.3 \mathrm{mmHg}, P=0.03$ ) and improved glucose metabolism (HbA1c (absolute difference $=-0.1 \%, P=0.0006)$ ) were observed during once-daily modified release hydrocortisone treatment. A sustained serum cortisol profile $0-4 \mathrm{~h}$ after the morning intake and reduced late afternoon and 24-h cortisol exposure compared to thrice-daily conventional hydrocortisone treatment was also seen

Patients had elevated triglycerides $(P=0.001)$, reduced HDL $(P<0.001)$ and nonesterified fatty acids $(P<0.001)$, elevated hs-CRP $(P<0.001)$ and small dense LDL $(P=0.002)$ compared to controls

More patients than controls were prescribed cardiovascular medicines(ATC C) (OER 1.14, 95\% Cl, 1.03-1.26). Patients $<40$ years of age used more antihypertensive drugs and diuretics than controls (OER 1.90,95\% Cl, 1.20-2.75)

Patients 40-49 years old were prescribed lipid-lowering agents more frequently than controls (OER 1.97, 95\% Cl, 1.15-3.01)

South African patients had higher median triglycerides $(P<0.001)$, total cholesterol $(P<0.001]$, LDL $(P<0.001)$, and median hs-CRP $(P<0.003)$ and lower HDL $(P<0.001)$ than the Swedish patients

Moderately reduced BMD in the patients (mean Z-score reductions from -0.57 to -0.17 at various sites). No increase in fractures. Significant association between P-glycoprotein SNP and BMD reduction

No overall BMD reduction. Prednisolone associated with lower BMD and DHEA with higher BMD

DHEA replacement reversed ongoing loss of bone mineral density at the femoral neck $(P<0.05)$ but not at other sites; DHEA enhanced total body $(P=0.02)$ and truncal $(P=0.017)$ lean mass significantly with no change in fat mass

221 hip fractures $(6.9 \%)$ in patients with PAI and 846 $(2.7 \%)$ in the controls were observed, yielding increased risk of hip fracture in PAI $((\mathrm{HR})=1.8 ; 95 \% \mathrm{Cl}, 1.6-2.1$; $P<0.001)$. Women diagnosed with $\mathrm{PAI} \leq 50$ years old had the highest risk of hip fracture $(\mathrm{HR}=2.7 ; 95 \% \mathrm{Cl}, 1.6-4.5)$

CGMS, continuous glucose monitoring system; BP, blood pressure; HbA1C, glycated haemoglobin; hs-CRP, highly sensitive C-reactive protein; OER, observed to expected ratio. 
normal fasting glucose levels, but a higher percentage of impaired glucose tolerance than in controls (81). Studies in secondary adrenal insufficiency indicate that altered circadian cortisol patterns during replacement therapy affect both carbohydrate and lipid metabolism $(82,83)$, but the effects of glucocorticoid and growth hormone failure and their replacement are hard to distinguish. It is, however, likely that lack of night-time cortisol in patients on regular glucocorticoid replacement therapy confers risk of nocturnal hypoglycaemia, which may be a problem particular to patients with concomitant diabetes mellitus (84). Use of once-daily modified release hydrocortisone tablet (Plenadren, Viropharma Inc, Exton, PA, USA) resulted in decreased body mass index (BMI) and HbA1c compared with conventional hydrocortisone treatment $(43,85)$. Possibly, these findings were due to a beneficial reduction in 24-h hydrocortisone exposure, especially evident in the afternoon $(85,86)$.

Lipid status has been assessed in a number of DHEA replacement trials, but overall no significant baseline abnormalities or effects of the treatment have been noted. Some studies reported a slight increase in HDL cholesterol $(76,77)$, whereas others have found more dyslipidaemia in patients with PAI than in controls (81, 87). A description of the drug prescription patterns in Sweden showed a higher use of lipid lowering agents among PAI patients compared with population controls (15). Comparisons between different PAI cohorts are rare, but recently South African PAI patients were found to have a worse lipid profile than gender-, age- and BMI-matched Swedish PAI patients despite being treated with lower daily doses of hydrocortisone (88). This is interesting data and emphasises that environmental, dietary and/or genetic factors certainly contribute to regional differences in cardiovascular risk factors. The major clinical studies on metabolism are summarised in Table 2.

\section{Cancer}

Various autoimmune conditions have been associated with increased cancer incidence $(89,90,91)$. Cancer mortality was slightly increased in the Swedish PAI population-based registry study but was not confirmed in a Norwegian cohort $(92,93)$. Data from other parts of the world do not exist. The cancer incidence pattern in Swedish PAI patients showed only a modest increase in cancer risk (93). When excluding cancers detected within the first year after PAI diagnosis, which may represent a potential detection bias, the risk remained elevated only in patients with APS-1 and not in patients with isolated PAI or APS-2. Significantly higher incidences of oral cancers (ICD-7140-148), non-melanoma skin cancer (ICD-7191) and male genital system cancers (ICD-7177-179) were seen among patients. By contrast, less breast cancer (ICD-7170) than expected was observed.

\section{Mortality}

Before treatment with glucocorticoids and fludrocortisone became available in the 1950s, the majority of patients died shortly after diagnosis (2). The mortality in patients with chronic PAI on conventional therapy was for a long time considered similar to that of the background population (3). Recent studies, however, challenged this view $(7,92,93,94)$. Bergthorsdottir and coworkers performed a population-based epidemiological register study in Sweden (1987-2001) (94) and found an increased risk of death in both men (risk ratio (RR) 2.19; 95\% CI, 1.91-2.51) and women (RR 2.86; 95\% CI, 2.54-3.20). The excess mortality was ascribed to cardiovascular, malignant and infectious diseases. The risk was highest in the period close to diagnosis but remained elevated through the years. Concomitant diabetes mellitus contributed only to a limited extent (7\%) to the reduced life expectancy. Bensing and coworkers corroborated a more than two-fold increased mortality in PAI investigating the same Swedish registers, but over an extended period (1964-2004) (93). A detailed cause-specific analysis showed an increased mortality from all disease categories. Notable high risks were observed from endocrine and infectious diseases. Furthermore, the highest mortality was observed in patients diagnosed before 15 years of age and in patients with APS-1. The Norwegian survey was a retrospective search of electronic in- and outpatient registries covering at least 15 years in 57 national hospitals (92). The diagnosis was verified by endocrinologists, identifying 811 patients with PAI and 147 deaths. Contrary to the Swedish studies, no overall increased mortality was found, but in line with Swedish data, an excess mortality was observed in patients diagnosed before the age of 40 (standardized mortality rate (SMR) 1.50; 95\% CI, 1.09-2.01), particularly evident in men. Acute adrenal failure, infections and sudden deaths were all common causes of death.

A possible cause of the higher mortality observed in PAI is suboptimal replacement therapy. The conventional glucocorticoid doses may be too high, with possible negative metabolic and cardiovascular consequences, but low levels of androgens could also contribute. 
Concomitant autoimmune disease, such as autoimmune thyroid disease, T1D, POI and APS-1, probably aggravate the higher mortality seen in PAI $(93,95,96,97,98)$. At diagnosis, more than half of all PAI patients present with Addisonian crises and are critically ill with an increased risk of death $(3,92)$. Considering patients dying never diagnosed or diagnosed post-mortem, the mortality would be even higher than suggested by the recent studies.

A life-threatening adrenal crisis is, unfortunately, a common event in PAI on replacement therapy. Recent studies provide evidence of an annual incidence of adrenal crisis of $5-17 \%(16,99,100,101,102,103)$ and show that $47 \%$ of PAI patients have experienced at least one acute adrenal crisis after diagnosis (100). In the first prospective study on adrenal crisis a total of 423 patients (PAI, $n=221$; secondary adrenal insufficiency (SAI), $n=202$ ) were followed up for 2 years; 10 patients died during follow-up (PAI, $n=5$; SAI, $n=5$ ), and at least 4 deaths were associated with adrenal crisis (0.5 adrenal-crisis-related deaths per 100 patients-years) (101). The most important precipitating causes of adrenal crisis are gastrointestinal infections with vomiting and/or diarrhoea, other infectious diseases and fever. Other listed causes are surgery, trauma, emotional stress and cessation of glucocorticoid substitution. Concomitant diseases $(99,100,102)$ and previous adrenal crisis (101) increase the frequency. Even a minor stomach upset can provoke an Addisonian crisis, and in the event of an emergency medical staff must react with prompt administration of intravenous glucocorticoids and saline infusions. Education of patients and medical staff on how to adequately increase glucocorticoid doses, when to seek medical help and how to self-administrate parenteral hydrocortisone is important to prevent adrenal crisis $(104,105)$. All patients should be equipped with a hydrocortisone injection kit and a steroid card to improve safety. Recently, a European bilingual steroid emergency card has been designed to provide quick and potentially life-saving information to the healthcare worker in an emergency situation (106).

\section{Concluding comment}

In this article, we have summarised the current knowledge on the epidemiology, QoL and complications of PAI. There is a need for improvement of the treatment and monitoring of patients with PAI. Further epidemiological research and prospective follow-up of large unbiased cohorts are needed to unravel the medical and public health impacts of PAI.
Declaration of interest

S B, A-L H, E S H and K L declare that there is no conflict of interest that could be perceived as prejudicing the impartiality of the review. $\mathrm{OK}$ is a board member of Olink $A B$.

\section{Funding}

The writing of this review was supported by the FP7 project Euradrenal (grant no. 201167), the Swedish Research Council, Torsten and Ragnar Söderberg Foundations, the regional agreement on medical training and clinical research (ALF) between Stockholm County Council and Karolinska Institutet, and the Swedish Society for Medical Research. Moreover, The Norwegian Research Council and The Regional Health Authorities of Western Norway.

\section{Author contribution statement}

$\mathrm{S} B$ and $\mathrm{K} \mathrm{L}$ wrote and revised the manuscript. A-L $\mathrm{H}, \mathrm{E} \mathrm{S} \mathrm{H}$ and $\mathrm{O} K$ contributed in revising it.

\section{References}

1 Guttman P. Addison's disease. A statistical analysis of 566 cases and a study of the pathology. Archives of Pathology 193010 742-895.

2 Dunlop D. Eighty-six cases of Addison's disease. BMJ 19632 887-891. (doi:10.1136/bmj.2.5362.887)

3 Mason AS, Meade TW, Lee JA \& Morris JN. Epidemiological and clinical picture of Addison's disease. Lancet 19682 744-747. (doi:10.1016/S0140-6736(68)90948-3)

4 Nerup J. Addison's disease - clinical studies. A report fo 108 cases. Acta Endocrinologica 197476 127-141.

5 Kong MF \& Jeffcoate W. Eighty-six cases of Addison's disease. Clinical Endocrinology 199441 757-761. (doi:10.1111/j.1365-2265.1994. tb02790.x)

6 Willis AC \& Vince FP. The prevalence of Addison's disease in Coventry, UK. Postgraduate Medical Journal 199773 286-288. (doi:10.1136/pgmj.73.859.286)

7 Løvås K \& Husebye ES. High prevalence and increasing incidence of Addison's disease in western Norway. Clinical Endocrinology 200256 787-791. (doi:10.1046/j.1365-2265.2002.t01-1-01552.x)

8 Erichsen MM, Lovas K, Skinningsrud B, Wolff AB, Undlien DE, Svartberg J, Fougner KJ, Berg TJ, Bollerslev J, Mella B et al. Clinical, immunological, and genetic features of autoimmune primary adrenal insufficiency: observations from a Norwegian registry. Journal of Clinical Endocrinology and Metabolism 200994 4882-4890. (doi:10.1210/jc.2009-1368)

9 Betterle C \& Morlin L. Autoimmune Addison's disease. In Pediatric Adrenal Diseases, pp 161-172. Eds L Ghizzoni, M Cappa, G Chrousos, S Loche \& M Maghnie. Basel, Switzerland: Karger, 2011.

10 Olafsson AS \& Sigurjonsdottir HA. Increasing prevalence of Addison disease: results from a nationwide study. Endocrine Practice 201622 30-35. (doi:10.4158/EP15754.OR)

11 Jacobson DL, Gange SJ, Rose NR \& Graham NM. Epidemiology and estimated population burden of selected autoimmune diseases in the United States. Clinical Immunology and Immunopathology 199784 223-243. (doi:10.1006/clin.1997.4412)

12 Takayanagi R, Miura K, Nakagawa H \& Nawata H. Epidemiologic study of adrenal gland disorders in Japan. Biomedicine \& Pharmacotherapy 200054 (Supplement 1) 164s-168s.

13 Ross IL \& Levitt NS. Addison's disease symptoms - a cross sectional study in urban South Africa. PLoS ONE 20138 e53526. (doi:10.1371/ journal.pone.0053526) 
14 Laureti S, Vecchi L, Santeusanio F \& Falorni A. Is the prevalence of Addison's disease underestimated? Journal of Clinical Endocrinology and Metabolism 199984 1762. (doi:10.1210/jcem.84.5.5677-7)

15 Björnsdottir S, Sundstrom A, Ludvigsson JF, Blomqvist P, Kampe O \& Bensing S. Drug prescription patterns in patients with Addison's disease: a Swedish population-based cohort study. Journal of Clinical Endocrinology and Metabolism 201398 2009-2018. (doi:10.1210/jc.2012-3561)

16 Meyer G, Neumann K, Badenhoop K \& Linder R. Increasing prevalence of Addison's disease in German females: health insurance data 2008-2012. European Journal of Endocrinology 2014170 367-373. (doi:10.1530/EJE-13-0756)

17 Eisenbarth GS \& Gottlieb PA. Autoimmune polyendocrine syndromes. New England Journal of Medicine $20043502068-2079$.

18 Arlt W \& Allolio B. Adrenal insufficiency. Lancet 2003361 1881-1893.

19 Betterle C, Scarpa R, Garelli S, Morlin L, Lazzarotto F, Presotto F, Coco G, Masiero S, Parolo A, Albergoni MP et al. Addison's disease: a survey on 633 patients in Padova. European Journal of Endocrinology 2013169 773-784. (doi:10.1530/EJE-13-0528)

20 Husebye ES, Perheentupa J, Rautemaa R \& Kampe O. Clinical manifestations and management of patients with autoimmune polyendocrine syndrome type I. Journal of Internal Medicine 2009265 514-529. (doi:10.1111/jim.2009.265.issue-5)

21 Oftedal BE, Hellesen A, Erichsen MM, Bratland E, Vardi A, Perheentupa J, Kemp EH, Fiskerstrand T, Viken MK, Weetman AP et al. Dominant mutations in the autoimmune regulator AIRE are associated with common organ-specific autoimmune diseases. Immunity 201542 1185-1196. (doi:10.1016/j.immuni.2015.04.021)

22 Crown A \& Lightman S. Why is the management of glucocorticoid deficiency still controversial: a review of the literature. Clinical Endocrinology 200563 483-492. (doi:10.1111/cen.2005.63. issue-5)

23 Husebye ES, Allolio B, Arlt W, Badenhoop K, Bensing S, Betterle C, Falorni A, Gan EH, Hulting AL, Kasperlik-Zaluska A et al. Consensus statement on the diagnosis, treatment and follow-up of patients with primary adrenal insufficiency. Journal of Internal Medicine 2014275 104-115. (doi:10.1111/joim.2014.275.issue-2)

24 Howlett TA. An assessment of optimal hydrocortisone replacement therapy. Clinical Endocrinology 199746 263-268. (doi:10.1046/j.1365 2265.1997.1340955.x)

25 Peacey SR, Guo CY, Robinson AM, Price A, Giles MA, Eastell R \& Weetman AP. Glucocorticoid replacement therapy: are patients over treated and does it matter? Clinical Endocrinology 199746 255-261. (doi:10.1046/j.1365-2265.1997.780907.x)

26 Lovas K, Thorsen TE \& Husebye ES. Saliva cortisol measurement: simple and reliable assessment of the glucocorticoid replacement therapy in Addison's disease. Journal of Endocrinological Investigation 200629 727-731. (doi:10.1007/BF03344183)

27 Arlt W, Rosenthal C, Hahner S \& Allolio B. Quality of glucocorticoid replacement in adrenal insufficiency: clinical assessment vs. timed serum cortisol measurements. Clinical Endocrinology 200664 384-389. (doi:10.1111/j.1365-2265.2006.02473.x)

28 Smans L, Lentjes E, Hermus A \& Zelissen P. Salivary cortisol day curves in assessing glucocorticoid replacement therapy in Addison's disease. Hormones 201312 93-100.

29 Lovas K, Loge JH \& Husebye ES. Subjective health status in Norwegian patients with Addison's disease. Clinical Endocrinology 200256 581-588. (doi:10.1046/j.1365-2265.2002.01466.x)

30 Hahner S, Loeffler M, Fassnacht M, Weismann D, Koschker AC, Quinkler M, Decker O, Arlt W \& Allolio B. Impaired subjective health status in 256 patients with adrenal insufficiency on standard therapy based on cross-sectional analysis. Journal of Clinical Endocrinology and Metabolism 200792 3912-3922. (doi:10.1210/jc.2007-0685)

31 Gurnell EM, Hunt PJ, Curran SE, Conway CL, Pullenayegum EM, Huppert FA, Compston JE, Herbert J \& Chatterjee VK. Long-term DHEA replacement in primary adrenal insufficiency: a randomized, controlled trial. Journal of Clinical Endocrinology and Metabolism 2008 93 400-409. (doi:10.1210/jc.2007-1134)

32 Bleicken B, Hahner S, Loeffler M, Ventz M, Allolio B \& Quinkler M. Impaired subjective health status in chronic adrenal insufficiency: impact of different glucocorticoid replacement regimens. European Journal of Endocrinology 2008159 811-817. (doi:10.1530/EJE-08-0578)

33 Alkatib AA, Cosma M, Elamin MB, Erickson D, Swiglo BA, Erwin PJ \& Montori VM. A systematic review and meta-analysis of randomized placebo-controlled trials of DHEA treatment effects on quality of life in women with adrenal insufficiency. Journal of Clinical Endocrinology and Metabolism 200994 3676-3681. (doi:10.1210/jc.2009-0672)

34 Tiemensma J, Andela CD, Kaptein AA, Romijn JA, van der Mast RC, Biermasz NR \& Pereira AM. Psychological morbidity and impaired quality of life in patients with stable treatment for primary adrenal insufficiency: cross-sectional study and review of the literature. European Journal of Endocrinology 2014171 171-182. (doi:10.1530/EJE14-0023)

35 Kluger N, Matikainen N, Sintonen H, Ranki A, Roine RP \& SchalinJantti C. Impaired health-related quality of life in Addison's disease impact of replacement therapy, comorbidities and socio-economic factors. Clinical Endocrinology 201481 511-518. (doi:10.1111/ cen.2014.81.issue-4)

36 Meyer G, Hackemann A, Penna-Martinez M \& Badenhoop K. What affects the quality of life in autoimmune Addison's disease? Hormone and Metabolic Research 201345 92-95. (doi:10.1055/s-00000025)

37 Bleicken B, Hahner S, Loeffler M, Ventz M, Decker O, Allolio B \& Quinkler M. Influence of hydrocortisone dosage scheme on healthrelated quality of life in patients with adrenal insufficiency. Clinical Endocrinology 201072 297-304. (doi:10.1111/cen.2010.72.issue-3)

38 Thomsen AF, Kvist TK, Andersen PK \& Kessing LV. The risk of affective disorders in patients with adrenocortical insufficiency. Psychoneuroendocrinology 200631 614-622. (doi:10.1016/j. psyneuen.2006.01.003)

39 Tiemensma J, Andela CD, Pereira AM, Romijn JA, Biermasz NR \& Kaptein AA. Patients with adrenal insufficiency hate their medication: concerns and stronger beliefs about the necessity of hydrocortisone intake are associated with more negative illness perceptions. Journal of Clinical Endocrinology and Metabolism 201499 3668-3676. (doi:10.1210/jc.2014-1527)

40 Lovas K, Curran S, Oksnes M, Husebye ES, Huppert FA \& Chatterjee VK. Development of a disease-specific quality of life questionnaire in Addison's disease. Journal of Clinical Endocrinology and Metabolism 201095 545-551. (doi:10.1210/jc.2009-1711)

41 Oksnes M, Bensing S, Hulting AL, Kampe O, Hackemann A, Meyer G, Badenhoop K, Betterle C, Parolo A, Giordano R et al. Quality of life in European patients with Addison's disease: validity of the diseasespecific questionnaire AddiQoL. Journal of Clinical Endocrinology and Metabolism 201297 568-576. (doi:10.1210/jc.2011-1901)

42 Giordano R, Guaraldi F, Marinazzo E, Fumarola F, Rampino A, Berardelli R, Karamouzis I, Lucchiari M Manetta T, Mengozzi G et al. Improvement of anthropometric and metabolic parameters, and quality of life following treatment with dual-release hydrocortisone in patients with Addison's disease. Endocrine 201651 360-368. (doi:10.1007/s12020-015-0681-z)

43 Quinkler M, Miodini Nilsen R, Zopf K, Ventz M \& Oksnes M. Modified-release hydrocortisone decreases BMI and HbA1c in patients with primary and secondary adrenal insufficiency. European Journal of Endocrinology 2015172 619-626. (doi:10.1530/EJE-14-1114)

44 Gagliardi L, Nenke MA, Thynne TR, von der Borch J, Rankin WA, Henley DE, Sorbello J, Inder WJ \& Torpy DJ. Continuous subcutaneous hydrocortisone infusion therapy in Addison's disease: a randomized, placebo-controlled clinical trial. Journal of Clinical Endocrinology and Metabolism 201499 4149-4157. (doi:10.1210/ jc.2014-2433)

45 Oksnes M, Bjornsdottir S, Isaksson M, Methlie P, Carlsen S, Nilsen RM, Broman JE, Triebner K, Kampe O, Hulting AL et al. 
Continuous subcutaneous hydrocortisone infusion versus oral hydrocortisone replacement for treatment of Addison's disease: a randomized clinical trial. Journal of Clinical Endocrinology and Metabolism 201499 1665-1674. (doi:10.1210/jc.2013-4253)

46 Lovas K, Husebye ES, Holsten F \& Bjorvatn B. Sleep disturbances in patients with Addison's disease. European Journal of Endocrinology 2003 148 449-456. (doi:10.1530/eje.0.1480449)

47 Garcia-Borreguero D, Wehr TA, Larrosa O, Granizo JJ, Hardwick D, Chrousos GP \& Friedman TC. Glucocorticoid replacement is permissive for rapid eye movement sleep and sleep consolidation in patients with adrenal insufficiency. Journal of Clinical Endocrinology and Metabolism 200085 4201-4206. (doi:10.1210/jcem.85.11.6965)

48 Henry M, Wolf PS, Ross IL \& Thomas KG. Poor quality of life, depressed mood, and memory impairment may be mediated by sleep disruption in patients with Addison's disease. Physiology \& Behavior 2015151 379-385. (doi:10.1016/j.physbeh.2015.08.011)

49 Schultebraucks K, Wingenfeld K, Heimes J, Quinkler M \& Otte C. Cognitive function in patients with primary adrenal insufficiency (Addison's disease). Psychoneuroendocrinology 201555 1-7. (doi:10.1016/j.psyneuen.2015.01.025)

50 Tiemensma J, Andela CD, Biermasz NR, Romijn JA \& Pereira AM. Mild cognitive deficits in patients with primary adrenal insufficiency. Psychoneuroendocrinology 201663 170-177. (doi:10.1016/j. psyneuen.2015.09.029)

51 Burger HG. Androgen production in women. Fertility and Sterility 2002 77 (Supplement 4) S3-S5.

52 Labrie F, Luu-The V, Labrie C \& Simard J. DHEA and its transformation into androgens and estrogens in peripheral target tissues: intracrinology. Frontiers in Neuroendocrinology 200122 185-212. (doi:10.1006/frne.2001.0216)

53 Erichsen MM, Husebye ES, Michelsen TM, Dahl AA \& Lovas K. Sexuality and fertility in women with Addison's disease. Journal of Clinical Endocrinology and Metabolism 201095 4354-4360. (doi:10.1210/jc.2010-0445)

54 Arlt W, Callies F, van Vlijmen JC, Koehler I, Reincke M, Bidlingmaier M, Huebler D, Oettel M, Ernst M, Schulte HM et al. Dehydroepiandrosterone replacement in women with adrenal insufficiency. New England Journal of Medicine 1999341 1013-1020.

55 Hunt PJ, Gurnell EM, Huppert FA, Richards C, Prevost AT, Wass JA, Herbert J \& Chatterjee VK. Improvement in mood and fatigue after dehydroepiandrosterone replacement in Addison's disease in a randomized, double blind trial. Journal of Clinical Endocrinology and Metabolism 200085 4650-4656.

56 Miller KK, Biller BM, Beauregard C, Lipman JG, Jones J, Schoenfeld D, Sherman JC, Swearingen B, Loeffler J \& Klibanski A. Effects of testosterone replacement in androgen-deficient women with hypopituitarism: a randomized, double-blind, placebo-controlled study. Journal of Clinical Endocrinology and Metabolism 200691 1683-1690. (doi:10.1210/jc.2005-2596)

57 Bjornsdottir S, Cnattingius S, Brandt L, Nordenstrom A, Ekbom A, Kampe $\mathrm{O} \&$ Bensing S. Addison's disease in women is a risk factor for an adverse pregnancy outcome. Journal of Clinical Endocrinology and Metabolism 201095 5249-5257. (doi:10.1210/jc.2010-0108)

58 Brent F. Addison's disease and pregnancy. American Journal of Surgery 195079 645-652. (doi:10.1016/0002-9610(50)90329-1)

59 Osler M. Addison's disease and pregnancy. Acta Endocrinologica 1962 41 67-78.

60 Gradden C, Lawrence D, Doyle PM \& Welch CR. Uses of error: Addison's disease in pregnancy. Lancet 2001357 1197. (doi:10.1016/ S0140-6736(05)71786-4)

61 Hunt AB \& Mc CW. Pregnancy associated with diseases of the adrenal glands. American Journal of Obstetrics \& Gynecology 195366 970-987.

62 Albert E, Dalaker K, Jorde R \& Berge LN. Addison's disease and pregnancy. Acta Obstetricia et Gynecologica Scandinavica 198968 185-187. (doi:10.3109/00016348909009909)
63 Ambrosi B, Barbetta L \& Morricone L. Diagnosis and management of Addison's disease during pregnancy. Journal of Endocrinological Investigation 200326 698-702. (doi:10.1007/BF03347034)

64 Lindsay JR \& Nieman LK. The hypothalamic-pituitary-adrenal axis in pregnancy: challenges in disease detection and treatment. Endocrine Reviews 200526 775-799. (doi:10.1210/er.2004-0025)

65 Smith R. Parturition. New England Journal of Medicine 2007356 271-283.

66 Suliman AM, Freaney R, Smith TP, McBrinn Y, Murray B \& McKenna TJ. The impact of different glucocorticoid replacement schedules on bone turnover and insulin sensitivity in patients with adrenal insufficiency. Clinical Endocrinology 200359 380-387. (doi:10.1046/j.1365-2265.2003.01860.x)

67 Devogelaer JP, Crabbe J \& Nagant de Deuxchaisnes C. Bone mineral density in Addison's disease: evidence for an effect of adrenal androgens on bone mass. British Medical Journal (Clinical Research Edition) 1987294 798-800. (doi:10.1136/bmj.294.6575.798)

68 Florkowski CM, Holmes SJ, Elliot JR, Donald RA \& Espiner EA. Bone mineral density is reduced in female but not male subjects with Addison's disease. New Zealand Medical Journal 1994107 52-53.

69 Zelissen PM, Croughs RJ, van Rijk PP \& Raymakers JA. Effect of glucocorticoid replacement therapy on bone mineral density in patients with Addison disease. Annals of Internal Medicine 1994120 207-210. (doi:10.7326/0003-4819-120-3199402010-00005)

70 Valero MA, Leon M, Ruiz Valdepenas MP, Larrodera L, Lopez MB, Papapietro K, Jara A \& Hawkins F. Bone density and turnover in Addison's disease: effect of glucocorticoid treatment. Bone and Mineral 199426 9-17. (doi:10.1016/S0169-6009(08)80158-4)

71 Braatvedt GD, Joyce M, Evans M, Clearwater J \& Reid IR. Bone mineral density in patients with treated Addison's disease. Osteoporosis International 199910 435-440. (doi:10.1007/s001980050251)

72 Jodar E, Valdepenas MP, Martinez G, Jara A \& Hawkins F. Longterm follow-up of bone mineral density in Addison's disease. Clinical Endocrinology 200358 617-620. (doi:10.1046/j.13652265.2003.01761.x)

73 Løvås K, Gjesdal CG, Christensen M, Wolff AB, Almas B, Svartberg J, Fougner KJ, Syversen U, Bollerslev J, Falch JA et al. Gluc ocorticoid replacement therapy and pharmacogenetics in Addison's disease: effects on bone. European Journal of Endocrinology 2009160 993-1002. (doi:10.1530/EJE-08-0880)

74 Koetz KR, Ventz M, Diederich S \& Quinkler M. Bone mineral density is not significantly reduced in adult patients on low-dose glucocorticoid replacement therapy. Journal of Clinical Endocrinology and Metabolism 201297 85-92. (doi:10.1210/jc.2011-2036)

75 Callies F, Fassnacht M, van Vlijmen JC, Koehler I, Huebler D, Seibel MJ, Arlt W \& Allolio B. Dehydroepiandrosterone replacement in women with adrenal insufficiency: effects on body composition, serum leptin, bone turnover, and exercise capacity. Journal of Clinical Endocrinology and Metabolism 200186 1968-1972.

76 Christiansen JJ, Gravholt CH, Fisker S, Moller N, Andersen M, Svenstrup B, Bennett P, Ivarsen P, Christiansen JS \& Jorgensen JO. Very short term dehydroepiandrosterone treatment in female adrenal failure: impact on carbohydrate, lipid and protein metabolism. European Journal of Endocrinology 2005152 77-85. (doi:10.1530/ eje.1.01810)

77 Lovas K, Gebre-Medhin G, Trovik TS, Fougner KJ, Uhlving S, Nedrebo BG, Myking OL, Kampe O \& Husebye ES. Replacement of dehydroepiandrosterone in adrenal failure: no benefit for subjective health status and sexuality in a 9-month, randomized, parallel group clinical trial. Journal of Clinical Endocrinology and Metabolism $2003 \mathbf{8 8}$ 1112-1118. (doi:10.1210/jc.2002-020769)

78 Bjørnsdottir S, Saaf M, Bensing S, Kampe O, Michaelsson K \& Ludvigsson JF. Risk of hip fracture in Addison's disease: a populationbased cohort study. Journal of Internal Medicine 2011270 187-195. (doi:10.1111/j.1365-2796.2011.02352.x) 
79 Ueda K, Okamura N, Hirai M, Tanigawara Y, Saeki T, Kioka N, Komano T \& Hori R. Human P-glycoprotein transports cortisol, aldosterone, and dexamethasone, but not progesterone. Journal of Biological Chemistry 1992267 24248-24252.

80 Pariante $\mathrm{CM}$. The role of multi-drug resistance p-glycoprotein in glucocorticoid function: studies in animals and relevance in humans. European Journal of Pharmacology 2008583 263-271. (doi:10.1016/j. ejphar.2007.11.067)

81 Giordano R, Marzotti S, Balbo M, Romagnoli S, Marinazzo E, Berardelli R, Migliaretti G, Benso A, Falorni A, Ghigo E et al. Metabolic and cardiovascular profile in patients with Addison's disease under conventional glucocorticoid replacement. Journal of Endocrinological Investigation 200932 917-923. (doi:10.1007/BF03345773)

82 Al-Shoumer KA, Ali K, Anyaoku V, Niththyananthan R \& Johnston DG. Overnight metabolic fuel deficiency in patients treated conventionally for hypopituitarism. Clinical Endocrinology 199645 171-178. (doi:10.1046/j.1365-2265.1996.d01-1552.x)

83 al-Shoumer KA, Cox KH, Hughes CL, Richmond W \& Johnston DG. Fasting and postprandial lipid abnormalities in hypopituitary women receiving conventional replacement therapy. Journal of Clinical Endocrinology and Metabolism 199782 2653-2659. (doi:10.1210/ jcem.82.8.4129)

84 Meyer G, Hackemann A, Reusch J \& Badenhoop K. Nocturnal hypoglycemia identified by a continuous glucose monitoring system in patients with primary adrenal insufficiency (Addison's disease). Diabetes Technology \& Therapeutics 201214 386-388.

85 Johannsson G, Nilsson AG, Bergthorsdottir R, Burman P, Dahlqvist P, Ekman B, Engstrom BE, Olsson T, Ragnarsson O, Ryberg M et al. Improved cortisol exposure-time profile and outcome in patients with adrenal insufficiency: a prospective randomized trial of a novel hydrocortisone dual-release formulation. Journal of Clinical Endocrinology and Metabolism 201297 473-481. (doi:10.1210/jc.2011-1926)

86 Plat L, Leproult R, L'Hermite-Baleriaux M, Fery F, Mockel J, Polonsky KS \& Van Cauter E. Metabolic effects of short-term elevations of plasma cortisol are more pronounced in the evening than in the morning. Journal of Clinical Endocrinology and Metabolism 199984 3082-3092. (doi:10.1210/jcem.84.9.5978)

87 Ross IL, Bergthorsdottir R, Levitt NS, Schatz DA, Johannsson G \& Marais AD. Increased cardiovascular risk in South African patients with Addison's disease. Hormone and Metabolic Research 201345 905-910. (doi:10.1055/s-00000025)

88 Ross IL, Bergthorsdottir R, Levitt N, Dave JA, Schatz D, Marais D \& Johannsson G. Cardiovascular risk factors in patients with Addison's disease: a comparative study of South African and Swedish patients. PLoS ONE 20149 e90768. (doi:10.1371/journal.pone.0090768)

89 Ekstrom K, Hjalgrim H, Brandt L, Baecklund E, Klareskog L, Ekbom A \& Askling J. Risk of malignant lymphomas in patients with rheumatoid arthritis and in their first-degree relatives. Arthritis \& Rheumatology 200348 963-970.

90 Zendehdel K, Nyren O, Ostenson CG, Adami HO, Ekbom A \& Ye W. Cancer incidence in patients with type 1 diabetes mellitus: a population-based cohort study in Sweden. Journal of the National Cancer Institute 200395 1797-1800. (doi:10.1093/jnci/djg105)

91 Askling J, Brandt L, Lapidus A, Karlen P, Bjorkholm M, Lofberg R \& Ekbom A. Risk of haematopoietic cancer in patients with inflammatory bowel disease. Gut $2005 \mathbf{5 4}$ 617-622. (doi:10.1136/ gut.2004.051771)

92 Erichsen MM, Lovas K, Fougner KJ, Svartberg J, Hauge ER, Bollerslev J, Berg JP, Mella B \& Husebye ES. Normal overall mortality rate in Addison's disease, but young patients are at risk of premature death.
European Journal of Endocrinology 2009160 233-237. (doi:10.1530/EJE08-0550)

93 Bensing S, Brandt L, Tabaroj F, Sjoberg O, Nilsson B, Ekbom A, Blomqvist P \& Kampe O. Increased death risk and altered cancer incidence pattern in patients with isolated or combined autoimmune primary adrenocortical insufficiency. Clinical Endocrinology 200869 697-704. (doi:10.1111/cen.2008.69.issue-5)

94 Bergthorsdottir R, Leonsson-Zachrisson M, Oden A \& Johannsson G. Premature mortality in patients with Addison's disease: a population-based study. Journal of Clinical Endocrinology and Metabolism 200691 4849-4853. (doi:10.1210/jc.2006-0076)

95 Becker C. Hypothyroidism and atherosclerotic heart disease: pathogenesis, medical management, and the role of coronary artery bypass surgery. Endocrine Reviews 19856 432-440. (doi:10.1210/ edrv-6-3-432)

96 Berger B, Stenstrom G \& Sundkvist G. Incidence, prevalence, and mortality of diabetes in a large population. A report from the Skaraborg Diabetes Registry. Diabetes Care 199922 773-778.

97 Mondul AM, Rodriguez C, Jacobs EJ \& Calle EE. Age at natural menopause and cause-specific mortality. American Journal of Epidemiology 2005162 1089-1097.

98 Meloni A, Willcox N, Meager A, Atzeni M, Wolff AS, Husebye ES, Furcas M, Rosatelli MC, Cao A \& Congia M. Autoimmune polyendocrine syndrome type 1 : an extensive longitudinal study in Sardinian patients. Journal of Clinical Endocrinology and Metabolism 201297 1114-1124. (doi:10.1210/jc.2011-2461)

99 Smans LC, Van der Valk ES, Hermus AR \& Zelissen PM. Incidence of adrenal crisis in patients with adrenal insufficiency. Clinical Endocrinology 201684 17-22. (doi:10.1111/cen.12865)

100 Hahner S, Loeffler M, Bleicken B, Drechsler C, Milovanovic D, Fassnacht M, Ventz M, Quinkler M \& Allolio B. Epidemiology of adrenal crisis in chronic adrenal insufficiency: the need for new prevention strategies. European Journal of Endocrinology 2010162 597-602. (doi:10.1530/EJE-09-0884)

101 Hahner S, Spinnler C, Fassnacht M, Burger-Stritt S, Lang K, Milovanovic D, Beuschlein F, Willenberg HS, Quinkler M \& Allolio B. High incidence of adrenal crisis in educated patients with chronic adrenal insufficiency: a prospective study. Journal of Clinical Endocrinology and Metabolism 2015100 407-416. (doi:10.1210/ jc.2014-3191)

102 White K \& Arlt W. Adrenal crisis in treated Addison's disease: a predictable but under-managed event. European Journal of Endocrinology 2010162 115-120. (doi:10.1530/EJE-09-0559)

103 Ritzel K, Beuschlein F, Mickisch A, Osswald A, Schneider HJ, Schopohl J \& Reincke M. Outcome of bilateral adrenalectomy in Cushing's syndrome: a systematic review. Journal of Clinical Endocrinology and Metabolism 201398 3939-3948. (doi:10.1210/jc.2013-1470)

104 Repping-Wuts HJ, Stikkelbroeck NM, Noordzij A, Kerstens M \& Hermus AR. A glucocorticoid education group meeting: an effective strategy for improving self-management to prevent adrenal crisis. European Journal of Endocrinology 2013169 17-22. (doi:10.1530/EJE12-1094)

105 Leblicq C, Rottembourg D, Deladoey J, Van Vliet G \& Deal C. Are guidelines for glucocorticoid coverage in adrenal insufficiency currently followed? Journal of Pediatrics $2011 \mathbf{1 5 8}$ 492-498.e491.

106 Quinkler M, Hahner S, Johannsson G \& Stewart PM. Saving lives of patients with adrenal insufficiency: a pan-European initiative? Clinical Endocrinology 201480 319-321. (doi:10.1111/cen.2014.80. issue-3)

Received 22 December 2015

Revised version received 24 March 2016

Accepted 6 April 2016 